\title{
Repatriation outcomes affecting corporate ROI - a critical review and future agenda
}

\begin{abstract}
Traditional corporate expatriate assignments play a crucial role in driving Multinational Corporations' (MNCs') business. While expatriate management literature long concentrated on facilitating the employees' actual stay in the host countries, seminal research in the early 1990s demonstrated that their return home is entailed by crucial challenges as well. Scholarly interest in the topic of repatriation has increased considerably ever since. Over the past three decades, research has addressed a broad array of aspects to be considered upon the return of expatriates. Nevertheless, so far very few MNCs have formal repatriation strategies in place. However, by failing to manage the return of expatriates, firms jeopardize their corporate return on investment (cROI) of expatriation. Many of the repatriation outcomes discussed in existing research can have an effect on cROI, due to the fact that they create late but substantial costs and/or benefits for assigning MNCs. In order to further enhance the strategic integration of repatriation into the expatriate management process, as well as to pave the way for future research on this important topic, this study reviews the current state of repatriation literature from a cROIperspective. By examining 51 articles, we identify the range of cROI-affecting repatriation outcomes addressed so far, to then classify the variables encountered according to their cost and benefit potential to assigning firms. We thereby outline potential shortcomings in existing research, to eventually deduce an agenda for future research on repatriation that aims at maximizing cROI in the long run.
\end{abstract}

Keywords Repatriation outcomes; repatriation; repatriate; international assignment; expatriate management; corporate return on investment (cROI) 


\section{Introduction}

Global mobility has developed impressively and nowadays adopts various forms. Although current literature has begun to investigate new forms of expatriation, e.g. self-initiated expatriates, flexpatriates, and virtual assignees (Baruch, Dickmann, Altman, and Bournois 2013; Shaffer, Kraimer, Chen, and Bolino 2012), the traditional corporate expatriate assignment still takes up the most relevant role in driving Multinational Corporations' (MNCs) business (Brookfield Global Relocation Services 2015; McNulty, de Cieri, and Hutchings 2009). For globally operating firms, the delegation of employees to foreign subsidiaries not only serves as approach to filling skill or managerial gaps on-site but in the long run also helps to develop a cadre of internationally experienced managers (Caligiuri and Colakoglu 2007). Expatriation literature, however, long concentrated on preventing failures during the staff's actual stay overseas (e.g., Black, Mendenhall, and Oddou 1991; Tung 1982). The smooth repatriation back to the home country was taken for granted at first.

Yet, in the early 1990s, seminal work demonstrated that not only the employees' move abroad but also their return was potentially challenging. Researchers found that former expatriates tend to experiencing severe readjustment difficulties after having worked in a foreign country (Black and Gregersen 1991). This revelation marked the starting point for the development of an impressive research field on its own. Various studies nowadays address a broad array of aspects to be considered when managing repatriation, ranging from commitment issues (e.g., Gregersen and Black 1996) to repatriate careers (e.g., Kraimer, Shaffer, and Bolino 2009) to impacts on the relocation willingness of future expatriates (e.g., Bolino 2007). The diversity of the body of literature is certainly one of its strengths but also fosters inconsistency and fragmentation. For firms, developing holistic measures to manage the return of expatriates is thus aggravated. In fact, despite the massive growth of research on the topic over the past three decades, so far less than $15 \%$ of MNCs have formal repatriation strategies in place (Brookfield Global Relocation Services 2015).

However, failing to manage the return of expatriates not only creates ad-hoc problems upon the end of international assignments. More importantly, it jeopardizes the firms' returns from the investment itself. The corporate return on investment (cROI) of expatriation was defined as a calculation of any assignment-related financial and non-financial costs and benefits affecting MNCs (McNulty and Tharenou 2004). Given that repatriation is intended, those costs and benefits are not restricted to the preparation and expatriation phase, but instead occur upon the return home of expatriates as well. Scholars agree that during the repatriation phase, there is huge potential for late effects on cROI that are nevertheless substantial (McNulty and Inkson 2013; McNulty and Tharenou 2004; Welch, Steen, and Tahvanainen 2009). For instance, dysfunctional repatriate turnovers (e.g., Kraim- 
er, Shaffer, Harrison, and Ren 2012) can entail costs which are just as critical to firms as the ones deriving from expatriate withdrawals overseas (e.g., van der Heijden, van Engen, and Paauwe 2009). Incorporating repatriate knowledge on global business (e.g., Furuya, Stevens, Bird, Oddou, and Mendenhall 2009) can create benefits that sometimes even exceed those obtained from meeting objectives in foreign subsidiaries. Yet, current numbers show that more than $50 \%$ of total expatriate attrition happens within the first two years of repatriation, and that only half of all MNCs have implemented processes to capture the experience of repatriates who remain with the firm (Brookfield Global Relocation Services 2015).

The rapid development of repatriation literature suggests there are many more outcomes entailed by the return of expatriates that can impact the cROI of expatriation. Yet, little work systematically links this still emerging research field to the concept of cROI (McNulty and Inkson 2013; McNulty and Tharenou 2004). Neither have all variables meeting the definition of cROI-affecting repatriation outcomes yet been identified nor has their relationship to cROI been explicitly outlined. Such an approach, however, provides the opportunity to systematically structure the highly diversified body of literature in a way that emphasizes the need to strategically integrate repatriation into the overall expatriate management process. On this basis, an agenda for future research can be developed that aims at maximizing impacts of returning expatriates on cROI. So far, literature on the topic is still coined by a focus on the potential costs related to repatriates (e.g., Kraimer et al. 2012; Lazarova and Cerdin 2007), whereas the crucial strategic benefits to be gained remain remarkably under-researched (e.g., Furuya et al. 2009; Oddou, Osland, and Blakeney 2008).

Consequently, after more than 30 years of investigating repatriation, we believe it is about time to take a step back and evaluate the current state of this important research field. As scholarly work should aim at increasing management efficiency in practice, we set out to review repatriation literature from a cROI-perspective. Identifying cost and benefit drivers during repatriation that impact cROI helps to structure the diverse literature, as well as to underline the importance of strategically managing the return of expatriates. Thus, we begin by specifying our understanding of cROI-affecting repatriation outcomes. We thereby provide the theoretical basis for a systematic link between repatriation research and the concept of cROI. We proceed to describe our method of identifying literature that addresses cROI-affecting repatriation outcomes. Including 51 articles in our review, we demonstrate that the majority of repatriation research indeed focuses on variables that can impact the cROI of expatriation. We cluster the studies selected not only along the repatriation outcomes addressed but also with regard to the theories applied and research approaches taken. We thereby illustrate the theoretical as well as methodological development in the field. As the relative importance of distinct repatriation outcomes for cROI 
depends on the business environment of assigning firms, we also consider the industry and country context of research conducted to this date. We then proceed to classify the repatriation outcomes encountered relative to their impact on cROI, namely if they have a prevailing cost potential, an equal cost and benefit potential, or a prevailing benefit potential. We thereby not only reveal an inner consistency within the diverse field of repatriation research, but also highlight where management practices should target the avoidance of negative impacts on cROI, and where they should be designed to enhance the positive potential entailed. Finally, we draw on the results from our review to outline the most urgent needs for future investigation. Both practitioners and academics increasingly acknowledge the cost and benefit potential implied by repatriates (Brookfield Global Relocation Services 2015; Welch et al. 2009). Yet, in order to maximize impacts on the cROI of expatriation, repatriation research must be coordinated respectively. With our work, we hope to contribute to the systematic starting point of many more studies focusing on this subject.

\section{2 cROI-affecting outcomes of repatriation}

The discussion about return on investment (ROI) is relatively new to expatriate management research. About ten years ago, McNulty and Tharenou (2004) pointed out that few firms use appropriate methods to assess or improve the value of their global mobility programs. As a consequence, they were the first to provide a conceptualization of what they denoted as expatriate ROI (eROI). The applicability of traditional accounting measures to the field was questioned, given that international assignments constitute investments in employees. A purely number-driven estimation of value is very likely to fall short when it comes to the complex composition of human assets (Welch et al. 2009). EROI was therefore argued to not only draw on quantitative estimates. The experience of living and working abroad further generates intangible benefits and costs which need to be taken into account (McNulty, de Cieri and Hutchings 2013; McNulty and Inkson 2013; McNulty and Tharenou 2004; Welch et al. 2009). Hence, McNulty and Tharenou (2004) concluded eROI to be “(...) a calculation in which the financial and non-financial benefits to the MNC are compared with the financial and non-financial costs of the international assignment, as appropriate to the assignment's purpose" (p. 73).

It is crucial to note that the concept of eROI as introduced in 2004 primarily adopts a firm perspective. In a follow-up study in 2013, McNulty and colleagues state that "(...) much of the literature about expatriate ROI [eROI] is [actually] focused on corporate ROI [cROI] to the firm" (McNulty et al. 2013: p. 210). Yet, obviously not only the firms initiating the expatriation, but also the individual employees actually being on assignment expect benefits to arise from their efforts. Recent work by McNulty and colleagues therefore explicitly distinguishes cROI from the individual ROI (iROI) of expatriation (McNulty et al. 2013; McNulty and Inkson 2013). 
The latter was thereby defined as the "(...) perceived benefits that accrue to expatriates arising from international assignment experience in relation to professional and personal gains. This understanding “(...) draws on, and extends, what is commonly referred to as expatriates' "career capital'” (McNulty and Inkson 2013: p. 35).

It must be acknowledged at this point that cROI and iROI are partially related, as some factors impact both the individual and the organizational returns from expatriation. Nevertheless, especially in the age of protean (Hall 1976, 2004) and boundaryless careers (Arthur and Rousseau 1996), a differentiation of the two perspectives is essential. For instance, intra-organizational career development upon repatriation can generate benefits for firms as well as for employees, thus enhancing cROI and iROI equally (McNulty et al. 2009; McNulty et al. 2013). Yet, when repatriates are hired by another MNC upon return home to start a better job there, individual benefits are increased whereas cROI is negatively affected due to the failed retention of valuable human resources. Consequently, cROI and iROI of expatriation are introduced as two distinct concepts in literature (McNulty and Inkson 2013). Our research objective is to provide a systematic review of repatriation research that highlights the need for formal repatriation strategies to MNCs. Thus, in this study, we draw on the differentiation just outlined and concentrate on the firm perspective only. We refrain from investigating any costs or benefits exclusively related to the individual. Instead, we focus on what McNulty and Inkson (2013) describe as the cROI of expatriation.

To determine the cROI of expatriation, MNCs need to not only consider all costs and benefits “(...) irrespective of whether a cost is financial (e.g., cross-cultural training) and the corresponding benefit is nonfinancial (e.g., improved performance)" (McNulty and Tharenou 2004: p. 73); firms further have to acknowledge that assignment-related costs and benefits occur along the entire expatriation process. Owed to the steadily increasing research on the topic, the repatriation phase has thereby particularly gained in attention (Schmidt and Minssen 2007; Welch et al. 2009). Of course, the role of the expatriates' return home for the cROI of expatriation depends on the assignments' initial purpose, as some delegation programs do not intend the reintegration of repatriates (McNulty and Tharenou 2004). Yet, referring to several interviews with repatriates and Human Resource (HR) managers on that matter, Welch et al. (2009) report that "(...) the actual HR activities associated with managing the assignment process (...) were important, but discussions tended to return to the longer term benefits post-assignment and the need to balance that against the actual costs" (p. 1333).

Hence, given that repatriation is intended by MNCs, the meaning of related outcomes for cROI is increasingly recognized. Still, the management of cROI-affecting outcomes of repatriation remains insufficient in practice (Brookfield Global Relocation Services 2015). Drawing on the understanding of cROI as outlined above, we 
define cROI-affecting repatriation outcomes as any outcome of repatriation that can entail financial and/or nonfinancial costs or benefits to firms, and thereby impact the cROI of expatriation. CROI-affecting repatriation outcomes thus need to be taken into account to determine whether MNCs are eventually put in a position that is better or worse off compared to before the expatriation. Repatriation research addresses a diverse range of variables meeting the definition of cROI-affecting repatriation outcomes. The development of integrated management approaches is therefore impeded. Further, for firms it is not only crucial to know which aspects to consider but also why they need to be considered, i.e. in what way they can affect cROI. For instance, repatriate retention must be managed as an outcome of repatriation to prevent cROI from decreasing, rather than to enhance it in the long run. The loss of former expatriates upon return home entails costs for MNCs, whereas their successful retention in itself does not create any additional benefits compared to the situation before the assignment. However, repatriate performance must be managed as an outcome of repatriation to prevent cROI from decreasing as well as to enhance it in the long run. Declined performance after repatriation entails costs for MNCs, yet employee performance can also increase upon return, e.g. because of the knowledge acquired abroad. Crucial assignment-related benefits are thereby created. In the following, we first turn to screening repatriation literature for its addressing of variables in line with our definition of cROI-affecting repatriation outcomes. After having revealed the range of outcomes investigated so far, we then proceed to classify the variables encountered according to their cost and benefit potential to firms.

\section{Methods}

\subsection{Article selection}

The first goal of this study is to examine the current state of repatriation research for studies addressing variables in line with our definition of cROI-affecting repatriation outcomes. Thus, the first methodological step was to choose an appropriate database. Since we aimed at analyzing a comparably broad field of literature, using a database that provides extensive access to research of several disciplines was obligatory. We decided to follow the example of previous literature reviews in related fields (Altman and Shortland 2008; Berning and Holtbrügge 2012; Doherty 2013) by using the Business Source Complete (EBSCO host), as it is the world's most-used reference resource with more than 375 full-text and research databases available. We proceeded by selecting the target journals for our review. Given that the investigation of repatriation is not restricted to one scholarly discipline, we decided to include journals from the field of International, Human Resource, and Strategic Management. To reflect the global scope of research, we further determined on selecting journals in English language only, as those reach a worldwide audience. We confined our investigation to peer-reviewed journals to ensure 
comparable quality standards. Moreover, we turned to the VHB-Jourqual 2.1 ranking for information on the academic influence of the single outlets and included all journals ranked $\mathrm{C}$ and higher in our analysis. We then examined those journals fulfilling the criteria defined for existing research on repatriation.

In selecting the articles for investigation, we followed the systematic approach illustrated in Figure 1, first choosing the keywords for our search. To avoid restrictions in the results and facilitate a reflection of the entire field of repatriation literature with all its varieties, we opted for the very general terms repatriation and repatriate. We applied those keywords to our database, limiting the search to full-length research articles only (see also Altman and Shortland 2008; Berning and Holtbrügge 2012; Jormanainen and Koveshnikov 2012). To depict the evolution of the field from its early beginnings, we focused on work published from 1980 until the date of this research (October 2014). In line with our research objective, studies to be selected also needed to fulfill the requirement of setting a focus on traditional corporate expatriation. Only considering publications in the journals previously defined, this initial search resulted in a sample of 70 articles on the topic of repatriation.

By carefully reading the studies obtained, we divided them into those following an explorative research approach (qualitative and quantitative descriptive studies) and those investigating causal relationships (conceptual and quantitative studies). Regarding the first group, research not explicitly addressing cROI-affecting repatriation outcomes in the course of the investigation was eliminated. On the one hand, this constraint applied to work retrieved from EBSCO that - although listed when searching for the keywords 'repatriation' and 'repatriate' did not focus the return of expatriates other than as a secondary theme (e.g., Lauring and Selmer 2010). On the other hand, this restriction affected articles exclusively dedicated to individual repatriation outcomes such as repatriate career capital (e.g., Suutari and Mäkelä 2007), which impact the iROI of expatriation. Such outcomes might reflect on cROI indirectly, but do not entail any immediate assignment-related financial or non-financial costs or benefits to firms, and thus were not suitable for our analysis. Concerning the second group (analyzing causal relationships), research not investigating cROI-affecting repatriation outcomes as dependent variable was eliminated according to the same criteria (e.g., Jokinen, Brewster, and Suutari 2008). Finally, work generally drawing on empirical data collection had to fulfill the requirement of not having collected this data while employees are still on assignment, as results with regard to repatriation are then anticipative in nature (e.g., Stahl, Chua, Caligiuri, Cerdin and Taniguchi 2009). In other words, we only included studies on real repatriates. Work surveying target groups other than repatriates, e.g. HR managers, was included if the sample provided secondary data on observable cROI-affecting repatriation outcomes (e.g., Stroh 1995, turnover data). After having systematically refined the initial search results, the final sample consisted of 51 articles which all address repatriation 
outcomes that can have an effect on cROI. As this sample represents a considerable part of repatriation literature, the need to strategically manage the return of expatriates is clearly emphasized. The articles identified then were analyzed carefully with regard to their content. The exact procedure is described in the following.

--- Please insert Figure 1 about here ---

\subsection{Article analysis}

The second goal of this study is to extract and categorize the cROI-affecting repatriation outcomes addressed by the studies identified, in order to depict the range of variables investigated so far. Hence, the second methodological step was an in-depth analysis of the selected articles. For this purpose, we conducted a qualitative content analysis. This provides a systematic approach to reduce large amounts of text data to its essence by classifying it according to unifying categories (Mayring 2014; Weber 1985). As literature reviews usually entail the analysis of written material in form of academic articles, it can be assumed that most studies of this kind implicitly draw on qualitative content analysis, at least to some degree. Some even explicitly refer to the application of this method (e.g., Jormanainen and Koveshnikov 2012; Shaffer et al. 2012). This approach finds regular use in International, Human Resource, and Strategic Management literature (Duriau, Reger, and Pfarrer 2007).

As no systematic depiction of cROI-affecting repatriation outcomes has been provided yet, we intended to remain open to respective variables of any kind. We therefore decided to follow the example of other studies reviewing a comparably broad field of research (e.g., Jormanainen and Koveshnikov 2012) by combining qualitative content analysis with an inductive approach. We commenced by carefully reading each article in our sample. First, descriptive information on theoretical basis, research approach and sampling method was extracted. Next, we divided the sample according to the research method applied. From papers that have taken an explorative research approach, any text passage describing or discussing cROI-affecting repatriation outcomes was extracted. From papers investigating causal relationships, any dependent variable suiting the definition of cROIaffecting repatriation outcomes applied in this study was extracted as well. If necessary, the extracted text was then reduced by paraphrasing. Paraphrases with a similar content were consolidated, to be further reduced subsequently. The latter procedure was required for explorative studies only, as the papers focusing on causal relationships all explicitly named the distinct dependent variables analyzed.

Eventually, we concluded that existing literature on repatriation concentrates on variables that can be summarized within seven categories of repatriation outcomes: repatriate adjustment, repatriate retention, repatriate work attitudes, repatriate performance, repatriate career development, repatriate knowledge integration, and repatriate relocation and recommendation willingness. As suggested by Mayring (2014), the resulting cate- 
gories were again tested by reassigning each study in the sample to the distinct repatriation outcome(s) it focuses on. Coding reliability was established as both authors conducted this step independently, to then compare the results. Conflicting views were given in the case of four explorative articles, or $7.8 \%$ of the sample. These were jointly discussed until a solution was found which suited the opinion of both authors.

The third goal of this study is to classify the repatriation outcomes identified according to their impact on cROI, in order to reveal an overall structure in the literature. Therefore, overall categories were developed based on the findings on the repatriation outcomes in research. We were able to classify the seven subcategories of cROI-affecting repatriation outcomes into three overall categories. The first overall category consists of outcomes with a prevailing cost potential. It encompasses repatriate adjustment and retention. Both repatriation outcomes are prone to negative interferences upon repatriation, whereas having little opportunity for improvement in comparison to the situation before the international assignment. The second category consists of outcomes that have an equal cost and benefit potential. It encompasses repatriate work attitudes, performance, and career development. Although those variables can deteriorate during repatriation, existing research also points at their potential for enhancement in consequence of an international assignment. The final category consists of outcomes with a prevailing benefit potential. It covers repatriate knowledge integration and future relocation and recommendation willingness. As the existence of those variables depends inextricably on the international experience itself, their realization maintains a great benefit potential. Yet, technically their absence does not imply losses for firms in comparison to the situation before the expatriation.

For a graphical illustration of the seven subcategories of repatriation outcomes and their overall impact on cROI, please refer to Figure 2. In the following, we first give some descriptive information on the sample of articles analyzed, before we present the repatriation outcomes identified together with the respective studies in detail.

\section{--- Please insert Figure 2 about here ---}

\subsection{Descriptive information on articles investigated}

In order to depict the numerical and methodological evolution of the field, we first conducted a publication pattern analysis. Since we analyzed more than 30 years of research, we condensed the time scale into publication ranges of five years each, in order to make it comprehensible. As Figure 3 shows, the number of publications on repatriation outcomes that can affect cROI increased more or less steadily over the past three decades. The peak was reached within the publication range of 2005-2009. It appears that interest has dropped since then, as there are only eight publications from 2010 on until today. Yet, it must be taken into account that this literature review 
was conducted in the fall of 2014, implying that potentially more research has followed within the further course of this year. Non-descriptive quantitative research on the topic emerged within the time frame of 1990-1994, and from then on served as methodological basis to more than half of the studies that followed.

--- Please insert Figure 3 about here ---

To provide a more refined methodological understanding of the studies selected, we proceeded to analyze the samples of the empirical articles in greater detail. The respective information obtained is stated in Table 1 . Interestingly, we found that data on cROI-affecting repatriation outcomes has been collected primarily on an individual level. Only three of the studies thereby chose a longitudinal approach (i.e., Kraimer et al. 2012; Reiche 2012; Suutari and Brewster 2003). The number of repatriates surveyed is indicated clearly in most cases. With regard to interview studies, the publications investigated gathered data from 24 repatriates on average, with a minimum of 10 (Vidal, Valle, and Aragón 2007a) and a maximum of 50 (Jassawalla and Sashittal 2009) respondents. Questionnaire surveys retrieved answers from 138 repatriates on average, with a minimum of 40 (Feldman and Tompson 1993) and a maximum of 305 (Furuya et al. 2009; Stevens, Oddou, Furuya, Bird, and Mendenhall 2006) repatriates.

Although this aspect can be assumed to significantly impact the manifestation of repatriation outcomes, only three of the interview studies analyzed provided full information on the time that has passed since the return of the repatriates surveyed: Pinto, Cabral-Cardoso, and Werther (2012) stated to have addressed repatriates which returned within 18 months before interview conduction, whereas Bossard and Peterson (2005) and Jassawalla and Sashittal (2009) approached employees with a repatriation tenure of up to three, respectively six, years. On the contrary, most quantitative work provided this information. Numbers thereby range from majorities that returned within the last 12 (Lazarova and Caligiuri 2001; Lazarova and Cerdin 2007) to 18 months (Black and Gregersen 1991; Black 1992) to two (Furuya et al. 2009; Kraimer et al. 2009; Ren, Bolino, Shaffer, and Kraimer 2013; Stevens et al. 2006; Vidal, Valle, and Aragón 2010) or three years (Benson and Pattie 2008; Stroh 1995). Some papers indicated average figures. In sum, repatriates surveyed by these studies had returned 15.4 months prior to data collection, with a minimum of seven (Forster 1994) and a maximum of 29.6 months (Suutari and Brewster 2003). Another interesting fact is that across all papers investigated giving information on gender distribution, on average, more than $80 \%$ of the participating employees were male.

Three studies conducted surveys or interviews among a mixed sample of repatriates and HR managers or superiors (i.e., Baruch, Steele, and Quantrill 2002; Furuya et al. 2009; Tung 1988). One approach carried out a survey among HR managers exclusively (i.e., Stroh 1995), yet with a focus on observable repatriation outcomes. 
Regarding the country of origin of the samples, the majority of data was collected in Europe exclusively (13 articles), closely followed by North American investigations (11 articles). Fewer studies were conducted in Asia (seven articles). Five of the empirical articles reviewed drew on a sample from more than one continent. While Lazarova and Cerdin (2007) collected data in Europe as well as North America, the approaches by Herman and Tetrick (2009), Kraimer et al. (2012) and Tung (1988) extended the predominant geographical focus by combining European, Asian, and/or North American samples with an Australian perspective. Feldman and Tompson (1993) eventually consulted a very diverse sample from all continents. Hence, due to the comparably high number of respective studies, findings on all seven categories of cROI-affecting repatriation outcomes identified in this article stem from European or North American repatriates, primarily. However, if we turn the tables and consider the four groups of articles sharing a common geographical sampling focus separately, it appears that some repatriation outcomes were addressed more frequently by the distinct groups than others. While repatriate adjustment is the repatriation outcome most often investigated by studies with European samples, almost half of all articles drawing on North American samples consider repatriate career development. Within the group of research in Asian countries, repatriate work attitudes are more frequently analyzed than any other repatriation outcome. Repatriate retention, eventually, was examined by three of the five mixed sample studies.

Whereas MNC home country information is consistently provided, only 23 of the 36 empirical studies further specified the industry which data originates from. From the indications given, it can be concluded that research has already focused on repatriates employed by organizations from diverse industry backgrounds, ranging from the services to the high-tech industry to institutions in the public sector (see Table 1). Yet, the industry selection appears rather random. We could not detect a relationship between industry focus and the consideration of certain repatriation outcomes.

Finally, we also observed the theories consulted by the studies analyzed. Table 1 therefore relates the repatriation outcome(s) addressed to the theoretical basis of the articles as well. It must be noted that due to their explorative nature, the qualitative and quantitative descriptive works investigated did not draw on distinct theories to structure their argumentation. However, the majority of articles analyzing causal relationships explicitly named their theoretical basis. About half of the studies thereby focused on one framework or theory only, whereas the other half combined the arguments of two or more perspectives in their model development. With the exception of one article (Furuya et al. 2009), the theories consulted argue on an individual level only. More precisely, earlier work on cROI-affecting repatriation outcomes notably often drew on the surprise and 
sense making framework by Louis (1980) to examine repatriate adjustment, retention, work attitudes, performance, and career development (Black 1992; Feldman 1991; Feldman and Tompson 1993; O'Sullivan 2002; Stroh, Gregersen, and Black 2000). The difficulties encountered in the context of general work transitions were here transferred to the phenomenon of returning expatriates. Together with the psychological contract theory (Rousseau 1989) and the protean career theory (Hall 1976, 2004), the surprise and sense making framework thus constitutes the theoretical basis mostly applied by research addressing repatriation outcomes with a prevailing cost potential. Within the group of studies considering repatriation outcomes with an equal costs and benefit potential, the framework is the mostly applied one as well. However, it is closely followed by the human capital theory (Becker 1993), a perspective that is adopted primarily to explain variance in repatriate career development (i.e., Benson and Pattie 2008; Bolino 2007; Cerdin and Le Pargneux 2009; Kraimer et al. 2009). Finally, when it comes to repatriate knowledge integration, knowledge and resource management theories such as the organizational knowledge creation theory (Nonaka 1994), the concept of careers as repositories of knowledge (Bird 1994), or the social resources theory (Lin, Ensel, and Vaughn 1981) were applied frequently. However, research on repatriation outcomes with a prevailing benefit potential is still scarce and in our analysis of theories consulted, no clear pattern could yet be detected.

--- Please insert Table 1 about here ---

\section{Presentation of findings and categorization}

We now turn to the detailed presentation of the cROI-affecting repatriation outcomes addressed by the articles we investigated. Each study and respective variable is discussed within the subcategory of repatriation outcomes it fits (i.e., repatriate adjustment, repatriate retention, etc.). The subcategories are in turn arranged according to the overall category they belong to (i.e., repatriation outcomes with a prevailing cost potential, a prevailing benefit potential, or an equal amount of both). Each subcategory is only reflected in one of the three overall categories. Yet, it is important to note that there are several studies addressing more than one cROI-affecting repatriation outcome in the course of their investigation. These articles are then presented in the context of more than one subcategory, accordingly. After discussing the findings on all repatriation outcomes belonging to one overall category, the respective relationship to cROI is outlined and the overall categorization thereby justified. Eventually, the state of research within the distinct overall category is summarized. Table 2 relates the articles investigated to the repatriation outcome(s) they address and the overall impact those outcomes can have on cROI. It thereby provides an overview of the current state and focus of research on cROI-affecting repatriation outcomes. 
4.1 Repatriation outcomes with a prevailing cost potential

We first discuss repatriation outcomes with a prevailing cost potential. The variables presented in this section are more likely to exert a negative than a positive effect on cROI.

\subsubsection{Repatriate adjustment}

Early research on repatriation first recognized that for employees who were on international assignments, coming back to the home country does not automatically imply that they feel home again. In his theoretical work, Harvey (1982) was the first to describe this repatriation dilemma. Exploring reasons for repatriates' difficulties in readjusting to the domestic corporate structure, he highlighted the experience of losing autonomy compared to the job performed abroad and being confronted with derailed career paths due to the long absence. It was not until 1991 that Black and Gregersen provided some empirical clarification on this phenomenon, describing repatriate adjustment difficulties to evolve as employees return to a supposedly familiar environment they now neither understand, nor know how to act appropriately in. Apparently, during their absence, not only their once wellknown work environment, but also they themselves changed (Black 1992). Thus, Black and Gregersen (1991) found readjustment to work to be more difficult for employees who were abroad for a comparably longer time span. In 1992, Black, Gregersen and Mendenhall then provided their conceptual framework on repatriate adjustment. They proposed that returning employees' level of adjustment is affected by their respective expectations and further individual-, job-, organization-, and non-work-related antecedents. Those factors exert their influence during repatriation, as well as expatriation, already. Starting with this milestone, work on repatriate adjustment increased rapidly. Various explorative studies provided insights on respective difficulties encountered by repatriates (Bossard and Peterson 2005; Forster 1994, 1997; Vidal et al. 2007a; Zvara and Singh 2004), whereby also accounting for the special situation of women (Linehan and Scullion 2002) and employees returning to emerging economies (Kulkarni, Lengnick-Hall, and Valk 2010). Most articles advised firms to clarify their repatriation process and provide programs to ease repatriates' returning home. In line with this argumentation, conceptual work on repatriate adjustment provided further insights into the facilitating impact of organizational support (Mezias and Scandura 2005; Shen and Hall 2009).

The influence of support practices was also considered in the original repatriate adjustment model suggested by Black et al. (1992). In parts or extended versions, this model was verified by several empirical studies, drawing on samples of Finnish (Gregersen and Stroh 1997; Suutari and Välimaa 2002) as well as Spanish (Vidal 
et al. 2010) repatriates. As one of few approaches, O’Sullivan (2002) moreover contemplated the influence of repatriate proactive behavior, such as information seeking or personal networking, on repatriate adjustment. In 2009, Herman and Tetrick picked up on this theoretical idea by empirically investigating the effect of individual coping strategies on repatriates' adjustment back home. Hence, in sum, research on repatriate adjustment has attracted quite some attention after initial findings revealed that after a longer time abroad, similar adjustment problems occurred as when expatriates first start their job in a foreign country.

\subsubsection{Repatriate retention}

When it comes to potential costs associated with repatriation, a large part of existing literature has been dedicated to repatriate turnover and retention. It must be acknowledged that turnover intention was frequently used as a proxy for actual turnover, as data on employees that have already left a firm is very hard to gather. In fact, very few studies based their investigation on actual turnover data (i.e., Baruch et al. 2002; Bossard and Peterson 2005; Kraimer et al. 2012; Stroh 1995; Suutari and Brewster 2003). We follow the example of the various studies in the field and present work focusing on turnover intention within the frame of repatriate retention. Yet, we do distinguish between articles that examined actual turnover and those that drew their results on turnover intention in the course of the discussion.

In a comprehensive conceptual study on repatriate job changes, Feldman (1991) considered retention upon return as a crucial sign of effectiveness. In line with this notion, later work regarded repatriate retention as indicator for expatriation success from an organizational perspective (Cerdin and Le Pargneux 2009; O’Sullivan 2002; Yan, Zhu and Hall 2002). Yet, in his large scale explorative work, Forster (1997) described $44 \%$ of the repatriates surveyed to exhibit intentions of leaving their employer after returning home. The implied notion of rather high rates of actual turnover was supported by interview studies of Baruch et al. (2002) and Bossard and Peterson (2005), and longitudinal observations by Suutari and Brewster (2003).

In their conceptual work, Black et al. (1992) were the first to systematically consider a connection between repatriate retention and other outcomes of repatriation. The authors proposed that repatriate turnover depends on the returning employees' level of adjustment and commitment, variables that are also analyzed in this study. So is job embeddedness, a work attitude that was described to also contributing to repatriate turnover intentions (Shen and Hall 2009). Drawing on psychological contract theory, Haslberger and Brewster (2009) stated that returning employees' intentions to leave a firm are enforced by breaches of the psychological contract they feel to have signed. Such breaches can occur in form of failed repatriation support and a lack of career development opportunities, among others (Haslberger and Brewster 2009). In his conceptual model, Bolino (2007) 
followed a related notion: he proposes that depending on the employees' initial motives to accept an expatriate assignment, a lack of career development upon returning home can lead to turnover.

Empirical work picked up the conceptual considerations just outlined. For instance, earlier studies verified that repatriate turnover (Stroh 1995) and turnover intentions (Feldman and Tompson 1993; Lazarova and Caligiuri 2001) correlate with the support assigning firms provide upon return. This relationship was also found to be true for Indian firms (Birur and Muthiah 2013) and thus goes beyond the context of developed market MNCs. Lazarova and Cerdin (2007) further demonstrated that regardless of the presence of organizational support practices, turnover intentions can also be fostered by protean and boundaryless career attitudes. Providing deeper insights into the black box, Lee and Liu (2007) not only revealed a connection of intentions to quit with the repatriates' adjustment, but also with the level of their organizational commitment and job satisfaction. The latter connection was further supported by research of Vidal, Valle, and Aragón (2007b, 2008).

Chi and Chen (2007) provided additional differentiation when revealing that turnover intentions can evolve due to counterfactual thoughts repatriates might develop when having unpleasant repatriation experiences. Eventually, Kraimer et al. (2009) and Kraimer et al. (2012) related turnover intentions to the career advancement upon return. They stated that a perceived lack of adequate career opportunities can lead to feelings of underemployment (Kraimer et al. 2009) and identity strain (Kraimer et al. 2012), which in turn contribute to repatriates' intent of leaving assigning firms. Overall, research quite substantially addressed matters of repatriate retention, both from a conceptual and an empirical standpoint.

\subsubsection{Categorization and summary}

We categorize repatriate adjustment and retention as repatriation outcomes with a prevailing cost and no to little benefit potential. From the MNCs' perspective, the repatriates' level of adjustment and intent to stay with the firm needs to be considered primarily to prevent cROI from decreasing. Both variables are obviously prone to negative impacts during repatriation. Existing research revealed that employees frequently experience readjustment difficulties after spending a longer time abroad, which - together with other factors - can even lead to their decision to leave the firm (Black et al. 1992; Vidal et al. 2010). Yet, traditional expatriation implies the delegation of employees that worked for the assigning firm already (Baruch et al. 2013). Retention is therefore likely to not have been an issue before. Also, people chosen to go abroad regularly perform well prior to their assignments (Brookfield Global Relocation Services 2015; Collings 2014). Their level of adjustment can thus be assumed to have been on a rather high level. Recovering such formerly valuable staff undergoing adjustment problems, which can in turn entail performance decreases (Black 1992; Vidal et al. 2010), implies substantial corpo- 
rate costs that are directly related to the expatriation. The risk of losing such employees weighs even heavier for MNCs

To avoid late costs, HR managers must thus aim to ensure adjustment and retention of former expatriates during repatriation. Yet, it must be acknowledged that if this strategy succeeds, no additional benefits are realized compared to the situation before the assignment. As outlined above, repatriates can be assumed to have been well-adjusted prior to their expatriation. Literature provided no indication that this state can be noticeably increased upon return from the host country. Retention can hardly be improved either, as employees either work for a firm or not. It can therefore be concluded that difficulties in repatriate adjustment and retention can negatively impact the cROI of expatriation, whereas a respective success in itself exerts neither a negative, nor overly positive impact. For MNCs, taking adjustment and retention into consideration when managing repatriation is crucial to maintain the cROI of expatriation stable rather than to enhancing it in the long run.

As our review demonstrates, literature on the cROI-affecting repatriation outcomes adjustment and retention is well-established. MNCs are likely to already be sufficiently informed about the potential risks related to those variables. A considerable number of explorative approaches created awareness for the problems associated with adjustment and turnover upon repatriation. Conceptual and empirical studies regularly consulted the surprise and sense making framework or the psychological contract theory to systematically investigate the challenge of returning to a home organization employees have long been absent from. Clarification on antecedents contributing to success or failure was thereby provided. While authors frequently pointed at the role of organizational support in this regard, several studies applying the protean career theory suggest that individual actions influence repatriate adjustment and retention as well. Yet, it needs to be acknowledged that when it comes to turnover, a rather small amount of existing research referred to actual turnover rates, whereas the majority surveyed repatriates' turnover intentions instead. Moreover, existing findings on repatriate adjustment and retention primarily originate from research in a European or North American context, with only few insights from Asian or other country samples.

\subsection{Repatriation outcomes with an equal cost and benefit potential}

Having addressed outcomes with a prevailing cost potential, we now turn to those with a balanced benefit and cost potential. These repatriation outcomes bear opportunities for negative as well as positive impacts on cROI, wherefore they should receive considerable attention of HR managers. 


\subsubsection{Repatriate work attitudes}

The category of repatriate work attitudes covers a rather broad set of variables analyzed in existing research. Providing a definition up-front is therefore necessary. Eagly and Chaiken (1993) described attitudes as "(...) a psychological tendency that is expressed by evaluating a particular entity with some degree of favor or disfavor" (p. 1). The response can occur in various forms, encompassing overt or covert, cognitive, affective, or behavioral reactions (Eagly and Chaiken 1993). In line with this definition, we consider repatriate work attitudes as any cognitive, affective, or behavioral expression of repatriates' evaluative responding towards their work environment, or certain domains of it.

A substantial part of repatriation research has been devoted to analyzing work attitudes. For instance, in his conceptual study on repatriate job changes, Feldman (1991) not only considered retention as a criterion for effectiveness, but further points at a moderate stress level and continued commitment to the firm. It appears that those variables are prone to the changes experienced by repatriates upon returning home. In their model on assignment success, Cerdin and Le Pargneux (2009) further proposed job satisfaction during repatriation as a factor which needs to be taken into account. However, based on the results of two large-scale explorative surveys, Forster $(1994,1997)$ revealed that repatriates exhibit lower levels of psychological well-being and job satisfaction than employees who have not been assigned abroad. Feldman and Tompson (1993) demonstrated that the level of stress and job satisfaction among repatriates not only depends on their demographic characteristics but further on support practices provided by assigning firms and individual coping strategies exhibited upon return. The impact of firm support on job satisfaction was affirmed by the work of Stevens et al. (2006). Two studies based on surveys among Spanish repatriates added the conclusion of it further depending on the accuracy of repatriation expectations and the job assigned upon return (Vidal et al. 2007b, 2008).

Repatriate commitment has also received considerable attention in research. In the early 1990s, Gregersen (1992) highlighted the difficulty of repatriates returning home and not only having to show commitment to a parent organization they were absent from for some time, but further to a work unit they are often newly assigned to. Based on an empirical investigation among American repatriates, he was able to verify the notion of dual commitment upon return (Gregersen 1992). A subsequent study, however, revealed that this differentiation is culture-specific: Japanese repatriates were found to only exhibit one global commitment to the overall organization, which was primarily affected by their perception of the firms' valuing of their international experience (Gregersen and Black 1996). Additional empirical research demonstrated that, like other work attitudes, repatriate commitment is affected by the accuracy of repatriation expectations held by employees (Stroh et al. 2000) 
and the support provided by the MNCs (Stevens et al. 2006). Yet, one study was not able to verify the latter relationship (i.e., Lazarova and Caligiuri 2001). Drawing on psychological contract theory, Chi and Chen (2007) eventually showed that the level of commitment upon repatriation also depends on repatriates' counterfactual thoughts and the fulfillment of the psychological contract, as perceived by returned employees. The former were already addressed in the context of retention. According to Chi and Chen (2007), upward counterfactual thinking implies thoughts such as "if only my employer had not sent me abroad, I would have been in a more pleasurable work environment" (p. 481). Downward counterfactual thinking describes the opposite, i.e. more positive attitudes. As such thoughts constitute cognitive reactions to the work environment, they can be considered a repatriate work attitude, and thus cROI-affecting repatriation outcome, on their own.

There are a few more work attitudes that have found comparably little attention in past repatriation research. In their conceptual work of 2009 , Shen and Hall introduced the multidimensional variable job embeddedness, proposing that repatriation success depends on the strength of repatriates' ties to their job, the surrounding people, community, and the firm. Job embeddedness was found to be negatively related to the individual changes repatriates have undergone during their time abroad, and positively connected with the personal investment made for realizing the expatriation experience. Linking work attitudes to career outcomes, Kraimer et al. (2009) stated that a lack of career advancement upon return can lead to a perception of underemployment among repatriates. In a related attempt, Kraimer et al. (2012) found that internationally experienced employees perceiving themselves as highly qualified can develop identity strains after repatriation in case their career desires are not satisfied.

Interestingly, Furuya et al. (2009) provided the only study explicitly suggesting the possibility of an enhancement of work attitudes upon repatriation, compared to prior to the expatriate experience. Based on a survey among Japanese repatriates, they were able to verify a positive relationship between the opportunity to apply the knowledge employees have gained abroad, and their level of job motivation during repatriation. Consequently, there is a large amount of - mostly empirical - work on various kinds of repatriate work attitudes. Yet, it must be acknowledged that some attitudes receive more attention than others.

\subsubsection{Repatriate performance}

Similar to retention and work attitudes, Feldman (1991) and Cerdin and Le Pargneux (2009) identified satisfactory employee performance as one of the crucial factors that should be considered when evaluating the success of repatriation processes. Due to the potential difficulties encountered, employee performance might suffer during repatriation. Feldman and Tompson (1993) therefore empirically investigated repatriate performance "(...) at 
the quality and quantity expected by relevant job supervisors" (p. 510). Among other findings, they stated that the assignment of a mentor can help in keeping performance on an appropriate level upon return.

Surprisingly, when compared to other repatriation outcomes outlined in this study, the performance of repatriates has found rather little attention in existing literature. It appears to have been primarily regarded as a consequence of adjustment. For instance, Black (1992) analyzed the effect of the accuracy of repatriates' expectations upon return on their performance and adjustment. Black et al. (1992) in their conceptual model then described performance losses to be one of the severe consequences of failed readjustment. This notion was carried further in the theoretical work of Zvara and Singh (2004). Eventually, Vidal et al. (2010) were able to verify the relationship between adjustment and performance for a sample of Spanish repatriates. Existing studies therefore often considered the risk for decreasing performance as motivation for investigating repatriate adjustment (e.g., Herman and Tetrick 2009; Kulkarni et al. 2010; Vidal et al. 2007a), instead of analyzing performance as a cROIaffecting repatriation outcome of its own.

Nevertheless, the approach of Furuya et al. (2009) again deserves attention in this regard. Like other researchers, they regarded performance as an indicator for repatriation effectiveness. Yet, they applied a perspective proposing that upon return from expatriation, employee performance cannot only be prevented from decreasing, but can actually be increased compared to before the experience. More precisely, the study revealed that repatriate performance can be enhanced by an application of the valuable international knowledge gained overseas. Thus, research on repatriate performance appears far less extensive than such on repatriate work attitudes, with some conceptual but comparably little empirical work existing, so far.

\subsubsection{Repatriate career development}

The value of repatriate knowledge gained abroad also plays a crucial role when it comes to the employees' objective career advancement back in the home organization. Repatriate career issues found relatively early attention in literature. Explorative work on repatriation revealed that upon return from their assignments, former expatriates often face career stagnation, or even derailment (Forster 1994, 1997; Tung 1988). Tung (1988) suggested that the 'out of sight, out of mind' syndrome is partially to blame: temporarily removed from corporate headquarters, assigned employees run the risk of losing touch with the parent firm. Such 'being off the organizational radar' seems to express itself by a lack of repatriation support, which can reflect negatively on employee careers upon returning home. Much explorative work on repatriation therefore addressed career and organizational support issues within a common context (Baruch et al. 2002; Bossard and Peterson 2005; Linehan and Scullion 2002; Jassawalla and Sashittal 2009; Suutari and Brewster 2003; Vidal et al. 2007a). The fact that employees 
with international experience appear to often feel entitled to further development within the assigning MNCs' boundaries is rather problematic. Ren et al. (2013) empirically demonstrated that in case of failed career development, or even career derailment, repatriates' subjective career satisfaction decreases significantly. Kraimer et al. (2009) further revealed that career issues are closely related to repatriate retention. Returnees not experiencing career advancements were found to be prone to developing negative work attitudes, which in turn increase the likelihood of their turnover (Kraimer et al. 2009).

However, exclusively regarding repatriate careers in the light of retention to reveal yet another risky antecedent of turnover falls short. Cerdin and Le Pargneux (2009), Feldman, (1991) and Yan et al. (2002) also considered repatriate career development as an indicator of repatriation success of its own. Even if those works primarily stressed the individual benefit, added value for MNCs is implied here. Jassawalla and Sashittal (2009) drew on results from their interview study when emphasizing the fact that systematic repatriate career development should be of highest priority to HR managers in order to harness the employees' knowledge and experience gained abroad in the long run. Peltonen (1997) called for HR managers to integrate international assignments into the individuals' overall career path in order to systematically develop future leaders valuable to firms.

Yet, thorough investigation of the modes of repatriate career development has remained scarce. In his conceptual model, Bolino (2007) proposed that the relation between expatriation and repatriate careers depends on international assignment features, the characteristics of the assigning firms the employees return to, and of course, on the support provided by those firms during the stay abroad and upon return. Other theoretical work further called on the employees themselves, suggesting that career advancement back in the home country also depends on their individual proactive behavior (O'Sullivan 2002). The little empirical work on the topic provided only few more insights. Kraimer et al. (2009) revealed a positive effect of developmental international assignments on the employees' subsequent job position. A study by Benson and Pattie (2008), however, found no impact of expatriation on the level of pay upon repatriation, and an even negative influence on the total number of promotions within the assigning MNCs' boundaries. Consequently, research on repatriate careers appears to be in need for further development, as several explorative and conceptual works have provided a basis, while more quantitative investigation is required.

\subsubsection{Categorization and summary}

We classify repatriate work attitudes, performance, and career development as repatriation outcomes with an equal cost and benefit potential to assigning firms. These variables need to be considered when strategically managing repatriation to prevent cROI from decreasing as well as to substantially enhance it in the long run. 
Existing research has suggested that the work attitudes, performance, and career development of former expatriates are prone to deteriorating during repatriation. It must thereby again be acknowledged that employees chosen for expatriation are typically high-performers, or at least such with a good track record (Brookfield Global Relocation Services 2015; Collings 2014). Research demonstrated that work attitudes serve as an indicator for performance (Bader and Berg 2013; Leavitt, Fong, and Greenwald 2011). The work attitudes of staff selected to go abroad can thus be assumed to have been rather high prior to expatriation. Respective employees might even have been a part of the firms' talent pipeline, waiting for the next step on the career ladder in order to contribute more of their potential to the MNCs (Brookfield Global Relocation Services 2015). If the work attitudes, performance, and career development of such staff decreases upon returning home, firms clearly lose in comparison to the situation before the assignment. Substantial non-financial and financial costs can come along, as future leadership potential formerly identified might now be lost. MNCs must thereby also take into account the relationship among the repatriation outcomes. A lack of career development was found to contribute to the evolvement of negative work attitudes (Kraimer et al. 2009; Kraimer et al. 2012; Ren et al. 2013). The work attitudes presented in this study were in turn argued to directly relate to the repatriates' decision to leave or stay with assigning firms (Bolino 2007; Chi and Chen 2007; Kraimer et al. 2009; Kraimer et al. 2012; Lee and Liu 2007; Shen and Hall 2009, Vidal et al. 2007b, 2008). In addition, work attitudes were found to be indicators of employee performance, in general (Bader and Berg 2013; Leavitt et al. 2011).

However, scholarly findings have suggested that repatriate work attitudes, performance, and career development also bear potential for improvement compared to before the assignment. Hence, the foreign experience can actually be used to enhance attitudes, performance, and career development upon return. The knowledge and human capital gained during expatriation plays a crucial role in this regard. Furuya et al. (2009), for example, indicated that the integration of the knowledge repatriates obtained overseas serves as antecedent to a higher degree of job satisfaction and performance. Employee career development might not only be a consequence of the performance increase, but also serve as a multiplier in this regard. Research demonstrated that repatriate knowledge should at best be integrated where it can have an effect in order to receive ideal performance results (Carpenter and Sanders 2001; Daily, Certo, and Dalton 2000). Managers with foreign experience were, among others, found to have better leadership qualities (Gregersen, Morrison, and Black 1998). Thus, if internationally experienced repatriates acquire responsible positions, MNCs can benefit from their ability to cope with the challenges of a globalized business environment. Consequently, given that proper repatriation management not only prevents repatriate work attitudes, performance, and career development from decreasing but leads to their en- 
hancement instead, substantial corporate benefits can be created that increase the cROI of expatriation for MNCs.

Thus, we consider the potential for benefit and cost of repatriate performance, work attitudes, and career development to be relatively balanced. Yet, as our literature review shows, the majority of studies so far has concentrated on the risks implied, a fact that is underlined by the frequent application of the surprise and sense making framework as theoretical basis. Articles addressing repatriation outcomes with an equal cost and benefit potential have set a rather needs-driven focus on the repatriates' struggle to making sense of a formerly well-known environment back home. Considerable work has thus suggested that work attitudes can deteriorate upon repatriation. In order to avoid costs, researchers identified antecedents to maintaining them at a satisfactory level and avoiding negative work attitudes from developing. Very little research adopted a benefit-enhancing perspective, such as by applying knowledge management theories to stress the potential for increasing repatriate work attitudes. The same conclusion applies to performance, which is also underrepresented in such research with a cost-avoiding perspective, though. Eventually, career issues have been addressed frequently in explorative work, focusing on the potentially negative effects expatriation might have on repatriate careers. Some conceptual and empirical work has suggested influencing factors which might enhance or hurt repatriate careers. Yet, quantitative empirical results on the topic are scarce, wherefore there remains uncertainty around the basic relationship between expatriation and repatriate careers. MNCs can therefore be assumed to neither be sufficiently aware of the potential advantages to be gained with regard to repatriate work attitudes, performance, and careers, nor know of efficient approaches to exploit these benefits during repatriation. Furthermore, while existing research on work attitudes and performance drew on European, North American, Asian, and geographically mixed samples to an equal extent, repatriate career development has not yet been addressed in an Asian context at all. The field is therefore lacking insights into differences and specifics that might exist here and that could be owed specifically to the Asian culture.

\subsection{Repatriation outcomes with a prevailing benefit potential}

Finally, we now turn to variables with a prevailing benefit potential. Little risk is associated with these outcomes. Hence, HR managers should fully concentrate on unfolding their benefit potential in order to maximize the effects on cROI during repatriation. 


\subsubsection{Repatriate knowledge integration}

A topic in expatriate management that has received only little research attention so far is repatriate knowledge management. During their time working in a foreign country, expatriates gain valuable knowledge about aspects related to the host country and international business, such as cross-cultural interaction, languages, foreign markets, global networks, and leadership (Hocking, Brown and Harzing 2004, 2007). Put into practice, this knowledge can contribute to the overall performance of firms (Carpenter and Sanders 2001; Daily et al. 2000). Consequently, the integration of the knowledge gained abroad is one more outcome serving as indicator of success within conceptual models on repatriation effectiveness. Respective work thereby differentiated between the application of knowledge by repatriates themselves within the frame of their new job (Feldman 1991; Yan et al. 2002) and the transfer of knowledge to the home organization and colleagues (Cerdin and Le Pargneux 2009; Yan et al. 2002). As an interview study by Bossard and Peterson (2005) illustrated, repatriates are not always able to use the skills acquired abroad after returning home. In this regard, firm support, as well as individual proactive behavior, was proposed to be a facilitator of both, knowledge application and transfer (Feldman 1991; Lazarova and Tarique 2005; O'Sullivan 2002; Velde 2010). Oddou et al. (2008) demonstrated the complexity surrounding knowledge transfer upon return by suggesting that both the repatriate and the new home work unit need to be motivated and enabled to transfer, respectively receive, the knowledge gained abroad. The mutual relationship between the two parties moreover needs to be coined by an atmosphere of trust in order to facilitate transfer (Oddou et al. 2008).

It might be due to this complexity that quantitative research on repatriate knowledge integration is very scarce. Reiche (2012) provided one of the few studies in this regard. He chose a rather specific approach by investigating the application and transfer of host-unit knowledge that can still be accessed after returning home via the networks built abroad. Drawing on information from former inpatriates in German MNC headquarters, he revealed that the continued access, and thereby application and transfer of knowledge, depends on the strength of ties to the former host unit and the organizational repatriation support provided. Based on a survey among Japanese repatriates, Furuya et al. (2009) further found that the use of knowledge back home not only depends on the respective level of knowledge gained abroad and the existence of firm support practices, but also on the repatriates' adjustment upon returning home. Yet, as already mentioned above, research on repatriate knowledge integration appears to be still in its infancy, with some conceptual, but only very little empirical clarification provided so far. 


\subsubsection{Repatriate relocation/recommendation willingness}

The willingness of repatriates to relocate again has played a minor role in existing literature on repatriation outcomes. In his explorative studies, Forster $(1994,1997)$ found that repatriates' attitudes towards future international assignments are rather mixed. Similar results are presented by a later qualitative study of Pinto et al. (2012). Despite the difficulties respondents encountered during repatriation, the interviews led by Bossard and Peterson (2005) drew a different picture: out of the 20 repatriates, 15 were positive about going abroad again.

Interestingly, Pinto et al. (2012) not only illuminated the future relocation willingness of repatriates, but also their willingness to recommend the expatriation experience to colleagues. Again neglecting the difficulties they experienced during repatriation, most of the interviewees were willing to recommend expatriation, although there are indications that this disposition is less likely for employees who had been compelled to go abroad by their firm.

In the only conceptual study addressing the matter of future relocation, Bolino (2007) went one step further. He did not focus on the impact of repatriates' explicit recommendation on the relocation willingness of other staff. Instead, he proposed that observing the career development of returning expatriates might motivate other employees to accept international assignments - or to not accept, respectively. This conjuncture can be considered as kind of an implicit recommendation, as it draws on observation. Yet, no empirical investigation of this relationship has followed. Hence, research on repatriation outcomes in terms of the future relocation willingness of repatriates and their colleagues is yet underrepresented.

\subsubsection{Categorization and summary}

We classify repatriate knowledge integration and future relocation and recommendation willingness as repatriation outcomes with a prevailing benefit potential. Both aspects need to be considered when strategically managing repatriation to substantially enhance cROI over the long term. Due to the large popularity of the knowledgebased view of the firm (Grant 1996), research nowadays acknowledges the substantial value which knowledge yields for firms. To MNCs, knowledge on international business is especially vital. As stated before, repatriates that return from working in host countries are likely to having made diverse experiences regarding cultures, foreign markets, and global leadership (Hocking et al. 2004, 2007). An efficient integration of these valuable resources back at the home organizations can entail concrete benefits for globally operating firms. In fact, in the long run, it can even reflect on corporate performance (Carpenter and Sanders 2001; Daily, et al. 2000). Along with further reasons (Caligiuri and Colakoglu 2007), this also outlines the great need of MNCs for a qualified 
pool of expatriates-to-be. As recent research emphasized, ensuring expatriation willingness among eligible employees is a challenging task for firms (Froese, Jommersbach, and Klautzsch 2013). The more candidates MNCs can choose from, the higher the chances to get a good fit. The recommendation of former expatriates that already had the experience can directly contribute to the development of such a pool. If repatriates themselves are willing to relocate again, the range of potential staff to send abroad in the future is even enriched by experienced individuals able to cope with more challenging assignments.

However, if MNCs fail to ensure repatriate knowledge integration or relocation and recommendation willingness, no financial or non-financial costs are entailed compared to the situation before the assignment. The knowledge on international business and the first-hand experience to recommend assignments to colleagues has not existed prior to the expatriation. In case firms are not able to create advantages from this learning, great opportunities are wasted - yet, MNCs are not put in a position that is any worse than before the expatriation. Negative recommendations are of course a risk that needs to be taken into account; however, considering existing findings as well as the fact that employees have various potential gains motivating them to go abroad (McNulty et al. 2013), we argue that at this point, the possibility for benefits to be obtained prevails that for costs. This implies that when managing repatriate knowledge integration as well as recommendation and relocation willingness, a strict focus on the maximum exploitation of benefits should be applied by assigning firms.

Nevertheless, as can be concluded from the review, research so far has paid little attention to repatriate knowledge integration and future relocation and recommendation willingness. Explorative work in a primarily European context has created some awareness for the fact that relocation willingness, of repatriates as well as of other staff, is an outcome that should be considered during repatriation. Yet, a systematic approach to analyzing the relationship remains missing. Hence, HR managers are probably not yet aware of the antecedents that need to be considered when managing repatriate future relocation and recommendation willingness. Regularly applying theories from the field of knowledge and resource management, repatriate knowledge integration has received considerable conceptual attention. Still, there is very little empirical research on the topic. In order to increase the awareness of assigning firms for the benefits associated with repatriate knowledge, and to enable them to exploit these potential gains efficiently, more investigation in diverse country contexts is crucially needed. As mentioned before, Figure 2 graphically outlines the relationship between the repatriation outcomes identified in literature and the cROI of expatriation. 


\section{Implications for future research}

After having discussed the current state of research on cROI-affecting outcomes of repatriation, we now turn to the implications that our findings have for future research on the topic. To better structure this outlook, we differentiate between three categories for a further development of the research field: (1) advancement of research on cROI-affecting repatriation outcomes already addressed, (2) advancement of research on cROI-affecting repatriation outcomes not yet addressed, and (3) advancement of data base to empirical research on cROIaffecting repatriation outcomes.

\subsection{Advancement of research on cROI-affecting repatriation outcomes already addressed}

As our literature review shows, work on repatriation outcomes with prevailing cost potential is extensive. Research on risk associated with repatriate adjustment and retention is well-established, numerically as well as methodologically. Moreover, existing literature has created considerable awareness for difficulties related to repatriate work attitudes, performance, and careers. While extending the country focus beyond the prevailing European and North American context might provide additional insights, assigning firms are still likely to nowadays be more enlightened about problems encountered upon return of former expatriates, and the influencing factors that need to be considered for their prevention.

Consequently, future research should be advised to refrain from creating further awareness for repatriation failures. Instead, ways to enhance the cROI of expatriation after the expatriates' return home need to be stressed. To foster the strategic integration of repatriation into the expatriate management process, the advantages to be gained must be more clearly emphasized to MNCs. Further, antecedents to a systematic benefit creation must be analyzed to facilitate the development of appropriate repatriation strategies. Yet, empirical work on repatriation outcomes with equal or prevailing benefit potential is still scarce. The possibility to increase employee work attitudes, performance, and careers in comparison to before the assignment might therefore not yet be on every HR manager's agenda. The same applies to the systematic integration of the knowledge gained abroad, or the facilitating effect successful repatriates could have on the pool of expatriates-to-be. More research is therefore required, with a change of perspective away from repatriation struggles and towards repatriation value. The approach of investigating respective variables in a common context appears promising, as e.g. Furuya et al. (2009) did with repatriate knowledge integration, job motivation, and performance. In fact, repatriate knowledge - and thus, knowledge or resource management theories - might play a key role in this regard. More precisely, the successful integration of repatriate knowledge might not only increase work atti- 
tudes and performance, but thereby also positively affect repatriates' careers and their respective willingness to relocate again. Such outcomes, in turn, might further reflect on the relocation willingness of colleagues. Hence, to be able to maximize the impacts of returning expatriates on cROI, future empirical work should examine antecedents and consequences of repatriate knowledge integration, as little insights have been provided in this regard (Furuya et al. 2009; Reiche 2012).

Similar uncertainty remains around the matter of repatriate career development. As outlined, the professional advancement of repatriates might vary depending on whether newly gained knowledge is efficiently integrated back in the home organization or not. However, the kind and extent of the knowledge, skills, and competencies acquired abroad is likely to make a difference as well. This is why existing studies on repatriate careers primarily drew on the human capital theory to explain the relationship between the expatriate experience overseas and career development upon repatriation. Yet, so far only three studies empirically examined this effect (Benson and Pattie 2008; Kraimer et al. 2009; Ren et al. 2013). Moreover, one article thereby investigated subjective career advancement instead of objective changes (Ren et al. 2013). MNCs can thus be assumed to not be sufficiently informed about the factors driving the successful development of internationally experienced leaders upon repatriation. Therefore, reasons for differences in human capital acquisition in the host country, as well as other antecedents to varying career outcomes upon repatriation, must be revealed by future research in order to provide MNCs with managerial practices to enhance the value to be gained from repatriate career development.

Repatriate relocation and recommendation willingness has not received any empirical attention, despite the fact that impacts on cROI can be substantial. To ensure the existence of a qualified pool of future expatriates, it is of utmost importance to analyze how relocation willingness is affected during repatriation, and how the preservation of benefits in this regard can be further enhanced.

Eventually, it must be acknowledged that although this research aims at increasing the willingness of MNCs to implement repatriation strategies, corporate resources are very constrained. Thus, when conducting research on beneficial repatriation outcomes in the future, it might be of interest to not only consider the impact of firm support, as prevailingly done in existing literature. Firms might also be able to channel activities of individual employees in their interest, whereby saving resources is possible. As an increasing attention for the protean and boundaryless career theory by the literature reviewed indicates, emerging career attitudes can play a crucial role in this regard. So far, empirical work focused on risks associated. For instance, Lazarova and Cerdin (2007) found that emerging career attitudes foster turnover intentions upon return 
from an international assignment. Yet, conceptual work presented in the course of this article suggests that MNCs might also be able to take advantage of such attitudes. More precisely, O'Sullivan (2002) argued that former expatriates with a protean career attitude might be able to proactively enhance their adjustment, career development, and knowledge integration upon repatriation. The likelihood of retention might then again be increased. Thus, emerging career attitudes - i.e. the protean and boundaryless career theory - should be taken into account in the future when analyzing repatriation benefits, to inform MNCs how they can be directed in a way that increases cROI.

\subsection{Advancement of research on cROI-affecting repatriation outcomes not yet addressed}

This study provides an overview of cROI-affecting repatriation outcomes that have already been addressed in existing literature. Yet, those do not yet constitute the entire range of repatriation outcomes that can affect the cROI of expatriation. To enhance the MNCs' willingness to formulate repatriation strategies, conceptual and theoretical approaches applied to repatriation research must be extended. Future research must clarify that there exists an even broader array of corporate cost and benefit drivers than revealed so far. One crucial aspect that has received no empirical attention is the impact that the expatriation of one employee can have on other employees upon return, in particular his or her direct colleagues. The theoretical consideration of ramifications for the relocation willingness of other staff can be regarded as initial step in the right direction (Bolino 2007). However, it might be that work attitudes and performance of other employees are also affected during repatriation. Scholarly work demonstrated that the psychological well-being of individuals severely depends on their social network, with potentially positive as well as negative implications (Bader and Schuster 2015; Lincoln 2000). Upon repatriation, former expatriates are likely to become a part of the social network of their colleagues from the new work unit. Applying a costs-avoiding perspective, the experiences repatriates made abroad could then lead to feelings of insecurity or even jealousy among these colleagues, whereby provoking negative work attitudes. Decreased individual performance can be the eventual result (Bader and Berg 2013; Leavitt et al. 2011). Yet, applying a benefit-enhancing perspective, sharing repatriate knowledge with the colleagues upon return might also improve their work attitudes and performance. Hence, future research should consider social network theory, knowledge management theories, and related theoretical approaches to address other employee-related consequences of expatriation, which could entail late costs or benefits and thereby affect the overall cROI.

Another aspect that has not yet been analyzed is the phenomenon of rather immediate organizational changes that repatriates might cause. Existing research acknowledged that employees with international experi- 
ence can affect organizational outcomes, such as long term firm performance (Carpenter and Sanders 2001; Daily et al. 2000). Yet, due to the fundamental experiences made, it can be assumed that repatriates can also provoke more immediate changes in their direct work environment upon return. Innovation research literature, for example, suggested that educational diversity among employees reflects positively on their likelihood of introducing an innovation. Innovations thereby encompass new products and services, but also organizational changes (Østergaard, Timmermans, and Kristinsson 2011). Expatriates gathered other impressions and knowledge than their colleagues who stayed at home, undergoing a different personal education. During repatriation, this might affect the way of doing daily business in terms of team processes, organizational structures, and the like. Such outcomes might be antecedents, but do not have to be equal to repatriate performance. Hence, future research might want to go beyond the approach of applying primarily individual level theories to provide insights into changes of team, organizational, and process structure caused by repatriates in their new work environment, as those can have late effects on the cROI of expatriation.

\subsection{Advancement of data base to empirical research on cROI-affecting repatriation outcomes}

Finally, no matter if future research focuses on the investigation of repatriation outcomes already addressed or on those not yet considered, we suggest that sampling approaches serving as basis to empirical work should be advanced. First and foremost, the geographical and cultural focus of existing research in the field is rather restricted. Whether articles analyzed repatriation outcomes with a prevailing cost potential, prevailing benefit potential, or an equal amount of both, the vast majority of findings were derived from data collected in Europe or Northern America. We found that among the groups of studies with a common geographical sampling focus, the main research interest varies. Nevertheless, the current state of research on cROIaffecting repatriation outcomes does not yet do justice to the fact that the relative importance of repatriation outcomes for cROI is likely to depend on the distinct business environment of MNCs. For instance, whereas the integration of knowledge gained abroad is surely important to all globally operating firms, it might be of utmost relevance to the expanding MNCs from emerging economies. Assigning employees abroad with the aim of gathering knowledge on international business (Hocking et al. 2004) can help firms from e.g. China and India to overcome their shortage of developed market knowledge and thus, to more quickly evolve from global latecomers to global players (Chang, Mellahi, and Wilkinson 2009; Held and Berg 2014). However, due to the scarcity of research in Asian countries, no existing study analyzes the modes of successful repatriate knowledge integration back home in Chinese and Indian firms. This gap must be addressed, as the organizational context of an emerging market firm might demand strategies different from those for firms from developed markets. 
Moreover, not only the geographical location of the firms employees return to, i.e. the home country, is relevant to the importance and manifestation of repatriation outcomes. The country repatriates return from, i.e. the host country, must be considered as well. Sticking with the example just provided, regarding the fact that Chinese and Indian firms have been undertaking substantial investment activities in Europe (Holtbrügge and Kreppel 2012), the integration of knowledge that repatriates bring home from European countries might be more beneficial to the cROI of expatriation than a transfer of know-how from other areas of the world. However, Reiche (2012) found that successful knowledge integration upon return inter alia depends on the strength of still existing ties to the host country. The development of social ties is more challenging if the cultural distance between the host and the home country is rather large (Farh, Bartol, Shapiro and Shin 2010), such as in the case of European countries and China. Thus, host country characteristics might impede the creation of benefits from international assignments in some cases. Likewise, empirical work on expatriation in hostile environments, i.e. countries suffering from a particularly high risk of e.g. terrorism or violent conflict, outlined that on-site, expatriates encounter specific difficulties. These can be stress-provoked performance impediments due to the hostile environment as well as safety-related intra-family conflicts (Bader and Berg 2013, Bader, Berg, and Holtbrügge 2015). After their employer has put them through such an emotionally demanding experience, it seems likely for repatriates from respective destinations to be more prone to developing negative work attitudes back home, or even intentions to leave the firm. Hence, in some cases, host country characteristics might also enhance the likelihood of costs to occur during repatriation. Consequently, future work on repatriation needs to pay more attention to the home as well as the host country of former expatriates, in order to foster the MNCs' awareness for increased chances of costs or benefits entailed, and facilitate the development of respective management measures to maximize cROI.

Second, independently from the country context, our review reveals that empirical research surveying repatriates draws its investigation on an overwhelming majority of male employees. Despite the growing share of women in expatriation (Altman and Shortland 2008, Brookfield Global Relocation Services 2015), so far only one study exclusively focused on female repatriates (Linehan and Scullion 2002). The authors suggested that expatriation and repatriation might be associated with even more difficulties for female assignees in comparison to males, due to the pioneering role they obtain in many firms. Yet, female attributes might also be helpful, for instance when it comes to repatriate knowledge integration, which is found to depend on an atmosphere of trust (Oddou et al. 2008). Hence, we suggest that future research on repatriation outcomes should pay attention to 
obtaining mixed or even exclusively female samples in order to highlight similarities and differences in this regard, and allow for MNCs to manage repatriation, accordingly.

Third and finally, in order to strengthen insights on both cROI-affecting repatriation outcomes already addressed as well as those not yet addressed, we recommend future research to refrain from the prevailing approach of exclusively surveying repatriates. Existing studies suggest a high risk of turnover among repatriates. Yet, most works thereby drew their results on turnover intention data instead of examining actual turnovers. Learnings from research on the expatriation phase show that turnover rates are not always as high as depicted in literature (Harzing 1995). Consequently, in order to provide more clarification on the actual number of repatriate turnovers, and hence, their real risk to the cROI of expatriation, more empirical studies addressing HR managers and superiors who are able to provide secondary data are to be recommended. Such samples might also be able to provide further - and objective - information on repatriation outcomes such as performance and other staff relocation willingness. Together with data collected from repatriate colleagues, issues around repatriation outcomes associated with other employees, and organizational structures, that have not yet been investigated, could then be investigated as well.

\section{Conclusion}

With this study, we provided a systematic review of the current state of repatriation literature from a cROIperspective. We thereby emphasized the role of repatriates for the eventual returns from global mobility to firms, i.e. the cROI of expatriation, in order to highlight the need to strategically integrate repatriation into the overall expatriate management process. By differentiating between the cost- and benefit potential of repatriation outcomes addressed in research, we were able to show that despite the fact that repatriation research has evolved impressively over the past three decades, there are still considerable research gaps that should be addressed in the future in order to maximize the cROI of expatriation. Especially the advantages to be gained for firms during repatriation deserve further attention, above and beyond what has been considered in previous literature. We hope that with this review and the respective research implications deduced, we can inspire future work on the important topic of repatriation to broaden its perspective with regard to conceptual and theoretical approaches as well as to methods applied, in order to further support MNCs in preserving, and enhancing, their cROI of expatriation after the expatriates' return home. 


\section{References}

Altman Y, Shortland S (2008) Women and international assignments: taking stock - a 25-year review. Hum Resour Manage 47(2):199-216

Arthur MB, Rousseau DM (1996) The boundaryless career: a new employment principle for a new organizational era. Oxford University Press, New York

Bader B, Berg N (2013) An empirical investigation of terrorism-induced stress on expatriate attitudes and performance. J Int Manage 19(2):163-175

Bader B, Berg N, Holtbrügge D (2015) Expatriate performance in terrorism-endangered countries: the role of family and organizational support. Int Bus Rev, 24(5):849-860

Bader B, Schuster T (2015) Expatriate social networks in terrorism-endangered countries: an empirical analysis in Afghanistan, India, Pakistan, and Saudi Arabia. J Int Manage 21(1):63-77

Baruch Y, Dickmann M, Altman Y, Bournois F (2013) Exploring international work: types and dimensions of global careers. Int J Hum Resour Man 24(12):2369-2393

Baruch Y, Steele D, Quantrill G (2002) Management of expatriation and repatriation for novice global player. Int J Manpow 23(7):659-671

Becker, GS (1993) Human capital: a theoretical and empirical analysis, with special reference to education. University of Chicago Press, Chicago

Benson GS, Pattie M (2008) Is expatriation good for my career? The impact of expatriate assignments on perceived and actual career outcomes. Int J Hum Resour Man 19(9):1636-1653

Berning SC, Holtbrügge D (2012) Chinese outward foreign direct investment - a challenge for traditional internationalization theories? J Betriebswirtsch 62(3-4):169-224

Bird, A (1994) Careers as repositories of knowledge: a new perspective on boundaryless careers. J Organ Behav 15(15):325-344

Birur S, Muthiah K (2013) Turnover intentions among repatriated employees in an emerging economy: the Indian experience. Int J Hum Resour Man 24(19):3667-3680

Black JS (1992) Coming home: the relationship of expatriate expectations with repatriation adjustment and job performance. Hum Relat 45(2):177-192

Black JS, Gregersen HB (1991) When yankee comes home: factors related to expatriate and spouse repatriation adjustment. J Int Bus Stud 22(4):671-694

Black JS, Gregersen HB, Mendenhall ME (1992) Toward a theoretical framework of repatriation adjustment. J Int Bus Stud 23(4):737-760

Black JS, Mendenhall M, Oddou G (1991) Toward a comprehensive model of international adjustment: an integration of multiple theoretical perspectives. Acade Manage Rev 16(2):291-317

Bolino MC (2007) Expatriate assignments and intra-organizational career success: implications for individuals and organizations. J Int Bus Stud 38(5):819-835

Bossard AB, Peterson RB (2005) The repatriate experience as seen by American expatriates. J World Bus 40(1):9-28

Brookfield Global Relocation Services (2015) Mindful mobility - global mobility trends 2015 survey report. Brookfield

Caligiuri PM, Colakoglu S (2007) A strategic contingency approach to expatriate assignment management. Hum Resour Manage J 17(4):393-410

Carpenter MA, Sanders GW (2001) Bundling human capital with organizational context: the impact of international assignment experience on multinational firm performance and CEO pay. Acad Manage J 44(3):493511

Cerdin JL, Le Pargneux M (2009) Career and international assignment fit: toward an integrative model of success. Hum Resour Manage 48(1):5-25

Chang YY, Mellahi K, Wilkinson A (2009) Control of subsidiaries of MNCs from emerging economies in developed countries: the case of Taiwanese MNCs in the UK. Int J Hum Resour Man 20(1):75-95

Chi SCS, Chen SC (2007) Perceived psychological contract fulfillment and job attitudes among repatriates: an empirical study in Taiwan. Int J Manpow 28(6):474-488

Collings DG (2014) Integrating global mobility and global talent management: exploring the challenges and strategic opportunities. J World Bus 49(2):253-261

Daily CM, Certo ST, Dalton DR (2000) International experience in the executive suite: the path to prosperity? Strateg Manage J 21(4):515-523 
Doherty N (2013) Understanding the self-initiated expatriate: a review and directions for future research. Int J Manag Rev 15(4):447-469

Duriau VJ, Reger RK, Pfarrer MD (2007) A content analysis of the content analysis literature in organization studies: research themes, data sources, and methodological refinements. Organ Res Methods 10(1):5-34

Eagly AH, Chaiken S (1993) The psychology of attitudes. Harcourt Brace Jovanovich College Publishers, Fort Worth

Farh CIC, Bartol KM, Shapiro DL, Shin J (2010) Networking abroad: a process model of how expatriates form support ties to facilitate adjustment. Acad Manage Rev 35(3):434-454

Feldman DC (1991) Repatriate moves as career transitions. Hum Resour Manage Rev 1(3):163-178

Feldman DC, Tompson HB (1993) Expatriation, repatriation, and domestic geographical relocation: an empirical investigation of adjustment to new job assignments. J Int Bus Stud 24(3):507-529

Forster N (1994) The forgotten employees? The experiences of expatriate staff returning to the UK. Int J Hum Resour Man 5(2):405-425

Forster N (1997) 'The persistent myth of high expatriate failure rates': a reappraisal. Int J Hum Resour Man $8(4): 414-433$

Froese FJ, Jommersbach S, Klautzsch E (2013) Cosmopolitan career choices: a cross-cultural study of job candidates' expatriation willingness. Int J Hum Resour Man 24(17):3247-3261

Furuya N, Stevens MJ, Bird A, Oddou G, Mendenhall M (2009) Managing the learning and transfer of global management competence: antecedents and outcomes of Japanese repatriation effectiveness. J Int Bus Stud 40(2):200-215

Grant, RM (1996) Toward a knowledge-based theory of the firm. Strateg Manage J 17(Winter Special Issue):109-122

Gregersen HB (1992) Commitments to a parent company and a local work unit during repatriation. Pers Psychol 45(1):29-54

Gregersen HB, Black JS (1996) Multiple commitments upon repatriation: the Japanese experience. J Manage 22(2):209-229

Gregersen HB, Morrison AJ, Black JS (1998) Developing leaders for the global frontier. Sloan Management Review 40(1):21-32

Gregersen HB, Stroh LK (1997) Coming home to the arctic cold: antecedents to Finnish expatriate and spouse repatriation adjustment. Pers Psychol 50(3):635-654

Hall DT (1976) Careers in organizations. Goodyear Pub. Co, Pacific Palisades

Hall DT (2004) The protean career: a quarter-century journey. J Vocat Behav 65(1):1-13

Harvey MC (1982) The other side of foreign assignments: dealing with the repatriation dilemma. J World Bus 17(1):53-59

Harzing AWK (1995) The persistent myth of high expatriate failure rates. Int J Hum Resour Man 6(2):457-474

Haslberger A, Brewster C (2009) Capital gains: expatriate adjustment and the psychological contract in international careers. Hum Resour Manage 48(3):379-397

Held K, Berg N (2014) Facing discrimination by host country nationals - emerging market multinational enterprises in developed markets. In: Lundan S, Verbeke A, Van Tulder R (ed) Progress in international business research: multinational enterprises, markets and institutional diversity, Vol. 9. Emerald, Bingley, pp 417-441

Herman JL, Tetrick LE (2009) Problem-focused versus emotion-focused coping strategies and repatriation adjustment. Hum Resour Manage 48(1):69-88

Hocking J, Brown M, Harzing AWK (2004) A knowledge transfer perspective of strategic assignment purposes and their path-dependent outcomes. Int J Hum Resour Man 15(3):565-586

Hocking J, Brown M, Harzing AWK (2007) Balancing global and local strategic contexts: expatriate knowledge transfer, applications, and learning within a transnational organization. Hum Resour Manage 46(4):513-533

Holtbrügge D, Kreppel H (2012) Determinants of outward foreign direct investment from BRIC countries: an explorative study. Int Journal of Emerging Mkts 7(1):4-30

Jassawalla AR, Sashittal HC (2009) Thinking strategically about integrating repatriated managers in MNCs. Hum Resour Manage 48(5):769-792

Jokinen T, Brewster C, Suutari V (2008) Career capital during international work experiences: contrasting selfinitiated expatriate experiences and assigned expatriation. Int J Hum Resour Man 19(6):979-998

Jormanainen I, Koveshnikov A (2012) International activities of emerging market firms. Manage Int Rev 52(5):691-725 
Kraimer ML, Shaffer MA, Bolino MC (2009) The influence of expatriate and repatriate experiences on career advancement and repatriate retention. Hum Resour Manage 48(1):27-47

Kraimer ML, Shaffer MA, Harrison DA, Ren H (2012) No place like home? An identity strain perspective on repatriate turnover. Acad Manage J 55(2):399-420

Kulkarni M, Lengnick-Hall ML, Valk R (2010) Employee perceptions of repatriation in an emerging economy: the Indian experience. Hum Resour Manage 49(3):531-548

Lauring J, Selmer J (2010) The supportive expatriate spouse: an ethnographic study of spouse involvement in expatriate careers. International Business Review 19(1):59-69

Lazarova M, Caligiuri PM (2001) Retaining repatriates: the role of organizational support practices. J World Bus 36(4):389-401

Lazarova M, Cerdin JL (2007) Revisiting repatriation concerns: organizational support versus career and contextual influences. J Int Bus Stud, 38(3):404-429

Lazarova M, Tarique I (2005) Knowledge transfer upon repatriation. J World Bus 40(4):361-373

Leavitt K, Fong CT, Greenwald AG (2011) Asking about well-being gets you half an answer: intra-individual processes of implicit and explicit job attitudes. J Organ Behav 32(4):672-687

Lee HW, Liu CH (2007) An examination of factors affecting repatriates' turnover intentions. Int J Manpow 28(2):122-134

Lin, N, Ensel WM, Vaughn, JC (1981) Social resources and strength of ties. Am Sociol Rev 46(4):393-405

Lincoln KD (2000) Social support, negative social interactions, and psychological well-being. Soc Serv Rev 74(2):231-252

Linehan M, Scullion H (2002) The repatriation of female international managers: an empirical study. Int J Manpow 23(7):649-658

Louis MR (1980) Surprise and sense making: What newcomers experience in entering unfamiliar organizational settings. Admin Sci Quart 25(2):226-251

Mayring P (2014) Qualitative content analysis: theoretical foundation, basic procedures and software solution. http://nbn-resolving.de/urn:nbn:de:0168-ssoar-395173. Accessed 4 November 2014

McNulty Y, de Cieri H, Hutchings K (2009) Do global firms measure expatriate return on investment? An empirical examination of measures, barriers and variables influencing global staffing practices. Int J Hum Resour Man 20(6):1309-1326

McNulty Y, de Cieri H, Hutchings K (2013) Expatriate return on investment in the Asia Pacific: an empirical study of individual ROI versus corporate ROI. J World Bus 48(2):209-221

McNulty Y, Inkson K (2013) Managing expatriates: a return on investment approach. Business Expert Press, New York

McNulty Y, Tharenou P (2004) Expatriate return on investment: a definition and antecedents. International Journal of Management \& Organization 34(3):68-95

Mezias JM, Scandura TA (2005) A needs-driven approach to expatriate adjustment and career development: a multiple mentoring perspective. J Int Bus Stud 36(5):519-538

Nonaka I (1994) A dynamic theory of organizational knowledge creation. Organ Sci 5(1):14-37

Østergaard CR, Timmermans B, Kristinsson K (2011) Does a different view create something new? The effect of employee diversity on innovation. Res Policy 40(3):500-509

Oddou G, Osland JS, Blakeney RN (2008) Repatriating knowledge: variables influencing the 'transfer' process. J Int Bus Stud 40(2):181-199

O’Sullivan SL (2002) The protean approach to managing repatriation transitions. Int J Manpower 23(7):597-616

Peltonen T (1997) Facing the rankings from the past: a tournament perspective on repatriate career mobility. Int J Hum Resour Man 8(1):106-123

Pinto LH, Cabral-Cardoso C, Werther WB (2012) Compelled to go abroad? Motives and outcomes of international assignments. Int J Hum Resour Man 23(11):2295-2314

Reiche BS (2012) Knowledge benefits of social capital upon repatriation: a longitudinal study of international assignees. J Manage Stud 49(6):1052-1077

Ren H, Bolino MC, Shaffer MA, Kraimer ML (2013) The influence of job demands and resources on repatriate career satisfaction: a relative deprivation perspective. J World Bus 48(1):149-159

Rousseau DM (1989) Psychological and implied contracts in organizations. Employee Responsibilities and Rights Journal 2(2):121-139

Schmidt S, Minssen H (2007) Accounting for international assignments: the case of the German chemical industry. Journal of Human Resource Costing \& Accounting 11(3):214-228 
Shaffer MA, Kraimer ML, Chen YP, Bolino MC (2012) Choices, challenges, and career consequences of global work experiences: a review and future agenda. J Manage 38(4):1282-1327

Shen Y, Hall DT (2009) When expatriates explore other options: retaining talent through greater job embeddedness and repatriation adjustment. Hum Resour Manage 48(5):793-816

Stahl GK, Chua CH, Caligiuri P, Cerdin JL, Taniguchi M (2009) Predictors of turnover intentions in learningdriven and demand-driven international assignments: the role of repatriation concerns, satisfaction with company support, and perceived career advancement opportunities. Hum Resour Manage 48(1):89-109

Stevens MJ, Oddou G, Furuya N, Bird A, Mendenhall M (2006) HR factors affecting repatriate job satisfaction and job attachment for Japanese managers. Int J Hum Resour Man 17(5):831-841

Stroh LK (1995) Predicting turnover among repatriates: can organizations affect retention rates? Int J Hum Resour Man 6(2):443-456

Stroh LK, Gregersen HB, Black JS (2000) Triumphs and tragedies: expectations and commitments upon repatriation. Int J Hum Resour Man 11(4):681-697

Suutari V, Brewster C (2003) Repatriation: empirical evidence from a longitudinal study of careers and expectations among Finnish expatriates. Int J Hum Resour Man 14(7):1132-1151

Suutari V, Mäkelä K (2007) The career capital of managers with global careers. J Manage Psychol 22(7):628648

Suutari V, Välimaa K (2002) Antecedents of repatriation adjustment: new evidence from Finnish repatriates. Int J Manpow 23(7):617-634

Tung RL (1982) Selection and training procedures of U.S, European, and Japanese multinationals. Calif Manage Rev 25(1):57-71

Tung RL (1988) Career issues in international assignments. Acad Manage Exec 11(3):241-244

Van Der Heijden JAV, Van Engen ML, Paauwe J (2009) Expatriate career support: predicting expatriate turnover and performance. Int J Hum Resour Man 20(4):831-845

Velde CR (2010) Intercultural knowledge management. International Journal of Human Resource Development and Management 10(4):297-309

Vidal ES, Valle RS, Aragón IB (2007a) The adjustment process of Spanish repatriates: a case study. Int J Hum Resour Man 18(8):1396-1417

Vidal ES, Valle RS, Aragón IB (2007b) Antecedents of repatriates' job satisfaction and its influence on turnover intentions: evidence from Spanish repatriated managers. J Bus Res 60(12):1272-1281

Vidal ES, Valle RS, Aragón IB (2008) International workers' satisfaction with the repatriation process. Int J Hum Resour Man 19(9):1683-1702

Vidal ES, Valle RS, Aragón IB (2010) Analysis of the repatriation adjustment process in the Spanish context. Int J Manpow 31(1):21-41

Weber RP (1985) Basic content analysis. Sage Publications, Beverly Hills

Welch D, Steen A, Tahvanainen M (2009) All pain, little gain? Reframing the value of international assignments. Int J Hum Resour Man 20(6):1327-1343

Yan A, Zhu G, Hall DT (2002) International assignments for career building: a model of agency relationships and psychological contracts. Acade Manage Rev 27(3):373-391

Zvara P, Singh G (2004) Home sweet home: dealing with return to a home country after an assignment abroad. International Journal of Human Resources Development and Management 4(2):215-222 